\title{
Estimating biological reference intervals for cell blood counts in a dog population
}

\author{
Estimación de los intervalos biológicos de referencia para conteos celulares sanguíneos en una población \\ de perros
Estimando intervalos de referência biológica para contagens de células sanguíneas em uma população de cães

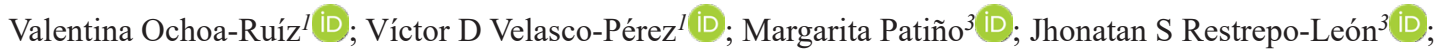
Jannet Zapata-Bailarín $^{1}$ (D); Nathalia M Correa-Valencia ${ }^{4}$ iD; Patricia E Jaramillo-Arbeláez ${ }^{1.2 *}$ iD.
\end{abstract}

\author{
${ }^{1}$ Escuela de Microbiología, Universidad de Antioquia, Medellín, Colombia. \\ ${ }^{2}$ Grupo HEMO, Escuela de Microbiología, Universidad de Antioquia, Medellín, Colombia. \\ ${ }^{3}$ Laboratorio TestLab, Medellín, Colombia. \\ ${ }^{4}$ Grupo Centauro, Escuela de Medicina Veterinaria, Facultad de Ciencias Agrarias, Universidad de Antioquía, Medellín, Colombia.
}

To cite this article:

Ochoa-Ruíz V, Velasco-Pérez VD, Patiño M, Restrepo-León JS, Zapata-Bailarín J, Correa-Valencia NM, Jaramillo-Arbeláez PE. Estimating biological reference intervals for cell blood counts in a dog population. Rev Colomb Cienc Pecu 2021; 34(2): 126-144. DOI: https://doi.org/10.17533/udea.rccp.v34n2a07

\begin{abstract}
Background: The results from automated equipment and peripheral blood smears allow correlating clinical data with cellular blood counts (CBC), generating information on pathologies of hematological and non-hematological origin in dogs. Objective: To describe qualitative and quantitative magnitudes of CBC in healthy donor dogs of a blood- bank in Medellín (Colombia). Methods: A descriptive-prospective study was carried out from 146 records of CBC results from a blood-bank. The samples were processed by automated equipment, and trained personnel performed the observation of peripheral blood smears to collect qualitative information. Variables such as age, sex, breed, quantitative results, and observations of the peripheral blood smears were considered. For the definition of biological intervals (BIs), the mean and two standard deviations were used for the data with a normal distribution. Otherwise, the 2.5th and 97.5th percentiles were used. Results: The size, granularity, and cytoplasmic vacuoles in monocytes and polymorphonuclear eosinophils, as well as the presence of Barr chromatin and occasional circulating erythroblasts, were remarkable findings to the peripheral blood smear. With the standardization of data obtained from dogs of large and giant breeds, the present work provides BIs for some of the CBC data in the studied population. Conclusion: The findings of the present study allow approximations to the definition of alterations in blood cells and their counts, which can guide the veterinarian towards an early diagnosis in dogs.
\end{abstract}

Keywords: Barr chromatin; biological intervals; blood; blood cells; canines; cellular count; chromatin; dog; erythroblasts; erythrogram; hematology; hemogram.

Received: March 25, 2020; accepted: August 26, 2020

*Corresponding author. Escuela de Microbiología, Universidad de Antioquia, UdeA. Tel: (+574) 2195495. Calle 67 \# 53-108, office 5-410, Medellín, Colombia. E-mail: pelena.jaramillo@udea.edu.co; patelen17@gmail.com 


\section{Resumen}

Antecedentes: Los datos obtenidos de equipos automatizados y extendidos de sangre periférica permiten correlacionar la clínica y los resultados del hemograma, generando información de interés sobre patologías de origen hematológico y no hematológico en perros. Objetivo: Describir las magnitudes cualitativas y cuantitativas del hemograma en perros sanos, donantes de un banco de sangre en Medellín (Colombia). Métodos: Se realizó un estudio descriptivo-prospectivo a partir de 146 registros de resultados de hemograma remitidos por un banco de sangre. Las muestras fueron procesadas por un equipo automatizado y personal entrenado realizó la observación del extendido de sangre periférica para la colección de información de corte cualitativo. Variables como edad, sexo, raza, resultados cuantitativos de las muestras y observaciones al extendido de sangre periférica fueron consideradas. Para la definición de intervalos biológicos (IBs) se utilizaron la media y dos desviaciones estándar para los datos con distribución normal. De lo contrario, se utilizaron los percentiles 2,5 y 97,5. Resultados: El tamaño, granularidad y vacuolas citoplasmáticas en monocitos y polimorfonucleares eosinófilos, así como la presencia de Cromatina de Barr y eritroblastos circulantes ocasionales fueron hallazgos llamativos al extendido de sangre periférica. Con la normalización de los datos para caninos de razas grandes y gigantes, el presente trabajo aporta IBs para algunos de los datos del hemograma en la población estudiada. Conclusión: Los hallazgos del presente estudio permiten aproximaciones a la definición de alteraciones en las células hemáticas y sus conteos, que pueden orientar al médico veterinario hacia un diagnóstico temprano en perros.

Palabras clave: caninos; células sanguíneas; conteo de células; cromatina de Barr; eritroblastos; eritrograma; hematología; hemograma; intervalos biológicos; perro; sangre.

\section{Resumo}

Antecedentes: As informações obtidas de equipamentos automatizados e esfregaços de sangue periférico permitem correlacionar os resultados clínicos e de hemogramas, gerando informações interessantes sobre patologias de origem hematológica e não hematológica em cães. Objetivo: Descrever as magnitudes qualitativa e quantitativa do hemograma em cães saudáveis, doadores de um banco de sangue em Medellín (Colômbia). Métodos: Foi realizado um estudo descritivo-prospectivo a partir de 146 registros de resultados de hemograma encaminhados por um banco de sangue. As amostras foram processadas por uma equipe automatizada e pessoal treinado observou o esfregaço de sangue periférico para a coleta de informações qualitativas. Foram consideradas variáveis como idade, sexo, raça, resultados quantitativos das amostras e observações do esfregaço de sangue periférico. Para a definição de intervalos biológicos (IBs), foram utilizados a média e dois desvios-padrão para os dados com distribuição normal. Caso contrário, foram utilizados os percentis 2,5 e 97,5. Resultados: O tamanho, a granularidade e os vacúolos citoplasmáticos dos monócitos e das células polimorfonucleares dos eosinófilos, bem como a presença da cromatina de Barr e ocasionais eritroblastos circulantes foram achados marcantes na disseminação do sangue periférico. Com a normalização dos dados para cães de raças grandes e gigantes, o presente trabalho fornece IBs para alguns dos dados de hemograma na população estudada. Conclusão: Os achados do presente estudo permitem aproximações à definição de alterações nas células sanguíneas e suas contagens, o que pode orientar o médico veterinário responsável pelo diagnóstico precoce em cães.

Palavras-chave: cão; canino; células sanguíneas; contagem de células; cromatina de Barr; eritroblastos; eritrograma; hematologia; hemograma; intervalos biológicos; sangue. 


\section{Introduction}

The use of cellular blood count (CBC) as a diagnostic, prognostic, and follow-up tool in hematological and non-hematological disorders is increasing in veterinary medicine of small animals. Additionally, the available automated technologies positively affect the test's sensitivity from a quantitative point of view. However, the contribution of microscopy with morphological reading of peripheral blood smear (PBS) allows for a closer approximation to timely diagnosis. Using such tools, a veterinarian can monitor the response to treatment, define the severity of a disease, and even support its prognosis (Barger, 2003).

A good starting point to obtain an appropriate interpretation of the results of a $\mathrm{CBC}$ is the understanding of normality of the findings, both quantitatively —with the values of the erythrogram, leukogram, and platelet counts, including histogram and dispersogram curves, as well as qualitative, detailing the morphological findings and recognizing the changes that occur under reactive and neoplastic conditions.

Several studies have established the values of clinical chemistry, hematology, and other physiological variables of different domestic and laboratory species worldwide. However, in Colombia, there are few studies reporting basic information on the main blood constituents in dogs and their morphological characteristics. Merizalde (2011) reported the biological reference intervals (BRIs), hematological counts, plasma proteins, blood pressure values, and electrocardiography findings in 300 healthy dogs in the Sabana de Bogotá, concluding that age, sex, breed, health status, as well as physiological variables such as excitation, muscle activity, environmental temperature, and altitude, can generate significant differences in the values obtained. Additionally, Bossa et al. (2012) carried out a study in Medellín to determine hematological BRIs in clinically healthy dogs from 1 to 6 years of age, leading to significant differences in some parameters of the $\mathrm{CBC}$ related to age. The scientific literature considers other aspects that could influence biochemical and hematological values, including the sample collection method, the puncture site, and the analysis method used (Castellanos and Castellano, 2010).

It should be highlighted that definition of accurate and robust BRIs, which allows for the correct interpretation of laboratory results, is an important and demanding task, from a methodological and scientific point of view (Ozarda et al., 2018). In 2010, the Clinical Laboratory Standards Institute (CLSI) EP28-A3c (previously C28-A3) established guidelines to define and verify BRIs' reports. The direct process considers selection criteria of the population as biological factors (e.g., age, sex, breed, reproductive status), clinical characteristics (history and physical examination to establish health and management practices), and geographical (location) and seasonal characteristics (effects of environmental temperature and day length). Likewise, it considers exclusion criteria, such as fasting or non-fasting previous to the sampling, intense exercise, level of stress or excitement, illness, lactation, pregnancy, administration of pharmacologically active agents, among others. Evidence of disease within a defined period preceding or following the sample collection should be considered for the exclusion of an individual. These inclusion and exclusion criteria are also used to differentiate reference populations into subgroups, for example, by age, sex, or reproductive status. Additionally, the number of healthy subjects available to provide reference samples is an important factor. Ideally, a minimum of 120 reference individuals from each breed should be available to determine the BRIs and corresponding confidence intervals (CIs) of $90 \%$ of the reference limits with enough additional individuals to allow some rejection. Reference intervals determined from smaller sample sizes are common and often necessary in veterinary medicine. However, it must be considered that the smaller the sample size, the greater the degree of uncertainty in the estimate (Walton, 2001).

Given the scarcity of reports, it is important to recommend information that allows a correct approximation to the definition of the BRIs to the $\mathrm{CBC}$ in the Colombian dog population, concerning the potential variability of the 
individuals (i.e., breed, sex, age). In addition, it is also necessary to provide information on the morphological characteristics of the hematopoietic cells in this species. Therefore, the objective of this study was to describe qualitative and quantitative magnitudes of $\mathrm{CBC}$ in healthy donor dogs of a blood-bank in Medellín (Colombia) from June 2017 to July 2018.

\section{Materials and Methods}

\section{Ethical considerations}

According to article $11^{\text {th }}$ of the resolution $n^{\circ}$ 8430 of 1993 of the Republic of Colombia, this study is considered of no-risk for using laboratory results of samples sent by a blood bank, with previous authorization by the laboratory performing the exams. No contact was made with the animals, nor were new interventions required for the animal, nor was there any data on the dogs that would allow contact with their owners. The data was protected using a code for its identification.

\section{Study design and population}

A descriptive-prospective cross-sectional study was carried out using a non-probabilistic and convenience sampling. The study population corresponded to $185 \mathrm{CBC}$ records and their respective colored blood slides; $39 \mathrm{CBC}$ of these were excluded because of a priori criteria, leading to a final sampling frame of $146 \mathrm{CBC}$ records. All the reports included the $\mathrm{CBC}$ results of healthy dogs referred by a blood-bank in the city of Medellín (Colombia), between June 2017 and July 2018. A healthy animal was defined according to the individual anamnesis, clinical examination, and the $\mathrm{CBC}$ results. All the processes related to the acceptance and/or rejection of individuals as blood-donors were carried out by the blood-bank veterinarians. The inclusion criteria, defined a priori by the bloodbank, were related to clinically healthy animals, weighing more than $25 \mathrm{Kg}$, between 1 and 8 years of age, hematocrit (HTC) $>40 \%$ (Jangsangthong, 2012), and DEA 1.1 negative (dog erythrocytic antigen). As exclusion criteria, defined a priori by the research team responsible for the present report, blood samples not suitable for the process (i.e., hemolysis, coagulation), low-quality smears (i.e., extended, coloration), and reports with missing or incomplete data were not considered in the analysis.

\section{Sample and information collection and handling}

Collection and handling of blood samples were carried out according to the routine established by the blood-bank, including the use of collection tubes with EDTA(ethylenediaminetetraacetic acid) and PBS performed at the time of sampling by trained personnel. The samples were processed in a veterinary clinical laboratory, where all procedures are accredited by the national standards ISO 17025 , by the Colombian Agricultural Institute (ICA). The automated equipment for the $\mathrm{CBC}$ is validated to process canine samples. The equipment is qualitatively controlled by internal low, medium, and high controls. The quantitative data of the CBC were generated using the HA-22 touch automated equipment (Clindiag Systems B.V.B.A, Zhenjiang, China) - with electric impedance technology, reporting the values of red blood cell count (RBC), HB (hemoglobin), HTC, mean corpuscular volume (MCV), medium corpuscular hemoglobin $(\mathrm{MCH})$, mean corpuscular hemoglobin concentration (MCHC), white blood cell count (WBC), platelet count (PLT), and mean platelet volume (MPV). The CBC considers a Gaussian curve, represented by histograms, being the basis for calculating MPV and MCV. The peripheral blood smear was carried out immediately after sample collection. The automated CBC process was carried out within one hour of collecting the sample, assuring sample stability.

Trained personnel carried out the observation of PBS for the qualitative information collection. Ten microscopic fields were considered, each with an average of 100 cells, using an objective of $10 \mathrm{X}$ to evaluate cell morphology, and $100 \mathrm{X}$ for total evaluation of 1,000 erythrocyte cells. In these fields, the erythrocyte and platelet morphology were read. Regarding leukocytes, 
100 cells were counted. To determine the size of the three cell lines, a $\mu \mathrm{m}$-scaled ruler was used under Wright-stain. Likewise, presence or absence of inclusions in erythrocytes, counting and presence or absence of granularity and/ or cytoplasmic inclusions in leukocytes, appearance of chromatin and nucleus, and presence or absence of granularity in platelets were observed.

Demographic information was obtained, such as identification of the animal (code), age, sex, and breed, from the records granted by the veterinary clinical laboratory.

\section{Statistical analysis}

For the statistical analysis, age, sex, and breed, sample quantitative results and observations to the PBS variables were considered. The information was recorded manually in Excel (Microsoft corp., Redmond, WA, USA) and analyzed using the statistical package SPSS v. 25, with parametric and non-parametric tests. The description of the study population was made using summary measures and absolute proportions. For the analysis of qualitative variables, the minimum and maximum values of each cell-line or number of cells that presented the characteristics of interest were estimated, depending on the case. For the analysis of the quantitative variables, the Grubbs test was used to detect aberrant data as well as extreme values; subsequently, measures of central tendency and dispersion were calculated by age, sex, and breed, considering a CI of $95 \%$. The Lilliefors test, based on the Kolmogorov-Smirnov test, was used to define the distribution of data. For the definition of biological intervals (BIs), the mean and two standard deviations were used for the data with a normal distribution (Solberg, 1987). Otherwise, the $2.5^{\text {th }}$ and $97.5^{\text {th }}$ percentiles were used.

\section{Results}

A total of 146 CBC records of healthy donor dogs from a blood-bank in Medellín (Colombia) and its corresponding PBS were analyzed. Table 1 shows the demographic characteristics of the study population.
Table 1. Frequency and distribution of a healthy dog population, donors of a blood-bank in Medellín (Colombia), by breed, sex, and age $(n=146)$.

\begin{tabular}{|c|c|c|}
\hline Breed & n of samples & Distribution (\%) \\
\hline Cross-breed & 34 & 23.3 \\
\hline Pitbull & 23 & 15.8 \\
\hline Golden retriever & 22 & 15.1 \\
\hline Labrador retriever & 18 & 12.3 \\
\hline Rottweiler & 16 & 11.0 \\
\hline German shepherd & 10 & 6.8 \\
\hline Siberian husky & 8 & 5.5 \\
\hline Basset hound & 3 & 2.1 \\
\hline Boxer & 3 & 2.1 \\
\hline Great Dane & 3 & 2.1 \\
\hline Rhodesian ridgeback & 2 & 1.4 \\
\hline Akita & 1 & 0.7 \\
\hline Beagle & 1 & 0.7 \\
\hline Bull terrier & 1 & 0.7 \\
\hline Weimaraner & 1 & 0.7 \\
\hline Total & 146 & 100.0 \\
\hline \multicolumn{3}{|l|}{ Sex } \\
\hline Male & 81 & 55.5 \\
\hline Female & 65 & 44.5 \\
\hline Total & 146 & 100.0 \\
\hline \multicolumn{3}{|l|}{ Age (years) } \\
\hline 1 & 18 & 12.3 \\
\hline 2 & 19 & 13.0 \\
\hline 3 & 30 & 20.5 \\
\hline 4 & 33 & 22.6 \\
\hline 5 & 24 & 16.4 \\
\hline 6 & 12 & 8.2 \\
\hline 7 & 6 & 4.1 \\
\hline 8 & 4 & 2.7 \\
\hline Total & 146 & 100.0 \\
\hline
\end{tabular}

Table 2 shows the sizes of the hematopoietic cells found in PBS. Particular observations (not mentioned in Table 2) were: Two samples had 1-2 macro-platelets, one of them of $7 \mu \mathrm{m}$, a polymorphonuclear (PM) neutrophil of $9 \mu \mathrm{m}$ in a sample from a cross-breed dog, and one of 17 $\mu \mathrm{m}$ from a Rottweiler, a PMN eosinophil of $8 \mu \mathrm{m}$ from a Pitbull, a $10 \mu$ mmonocytes in a Siberian husky, and a lymphocyte of normal morphology and of $15 \mu \mathrm{m}$ from a cross-breed dog. 
Table 2. Variable costs of three dairy systems in southern Brazil.

\begin{tabular}{|c|c|c|c|c|}
\hline \multirow{2}{*}{ Cell line } & \multirow{2}{*}{ n of cells } & \multirow{2}{*}{ Average size $(\mu \mathrm{m})$} & \multicolumn{2}{|c|}{ Size $(\mu \mathrm{m})$} \\
\hline & & & Minimum & Maximum \\
\hline Erythrocytes* & 14,600 & 6.67 & 5 & 8 \\
\hline PMs neutrophils & 8,948 & 12.55 & 10 & 15 \\
\hline PMs eosinophils & 1,632 & 6.67 & 10 & 17 \\
\hline PMs basophils & 47 & 13.43 & 11 & 15 \\
\hline Lymphocytes & 3,177 & 9.90 & 7 & 14 \\
\hline Reactive lymphocyte** & 29 & 13.32 & 11 & 17 \\
\hline Monocytes & 767 & 14.09 & 10 & 20 \\
\hline Platelets & 14,600 & 3.18 & 2 & 5 \\
\hline
\end{tabular}

PMs: Polymorphonuclears. *Figure 1. **Figure 2.

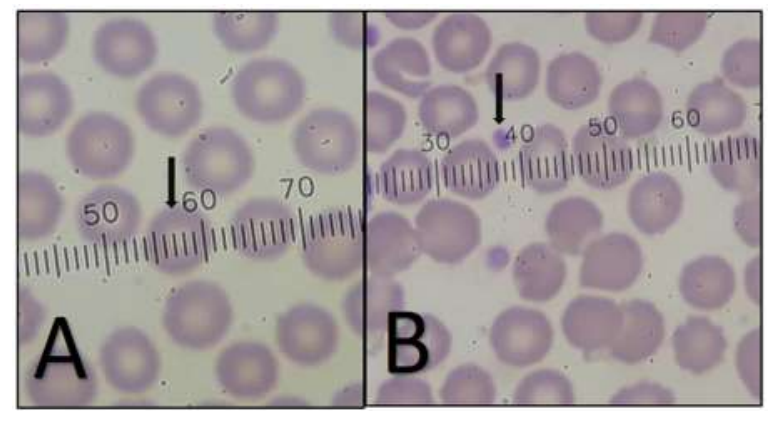

Figure 1. A) Size (average of 6.5; arrow) and morphology (normal) of erythrocytes; B) Size (2-3 microns; arrow) and morphology of platelets (100X magnification).

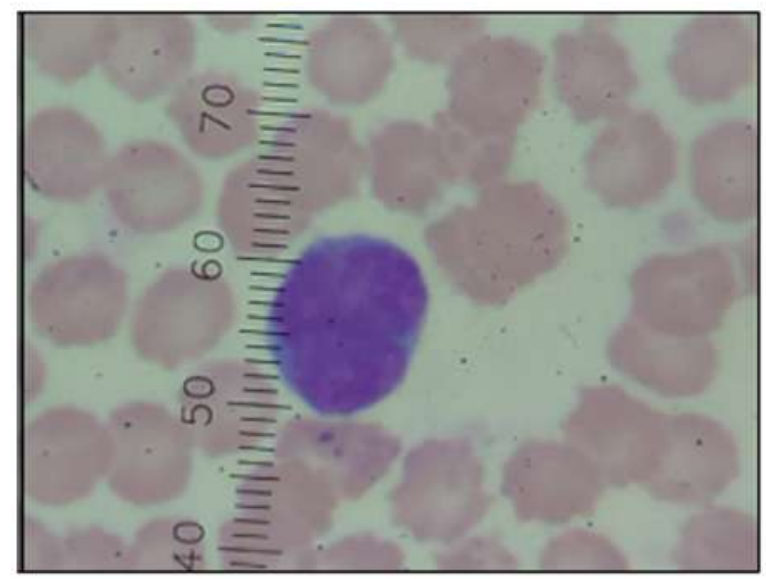

Figure 2. A reactive lymphocyte, with enlargement, a cleft nucleus (cloverleaf shape), and a little basophilic cytoplasm (the image was obtained from the thick part of the smear; therefore, it is considered as an incidental finding; 100X magnification).

Specific granules were observed in PMs neutrophils (Figure 3A), PMs eosinophils (Figure 3B), and in PMs basophils (Figures 3C and $3 \mathrm{D})$, as well as granularity inside platelets.
Samples of 38 dogs showed vacuoles in 1-14 PMs eosinophils (Figure 4A), of which the Weimaranerbreed was the only one that presented 14 vacuolated PMs eosinophils. Vacuoles were found inside between 1-8 monocytes (Figures 4B and 4C) in samples from 72 dogs, and occasional vacuolated PMs neutrophils were present. Although chromatin alterations were not observed, in 16 samples (from 3 males and 13 females) PMs neutrophils presented the appendix with morphological characteristic known as Barr chromatin (Figure 5). No inclusions were observed in the erythrocytes, nor polychromatophilia.

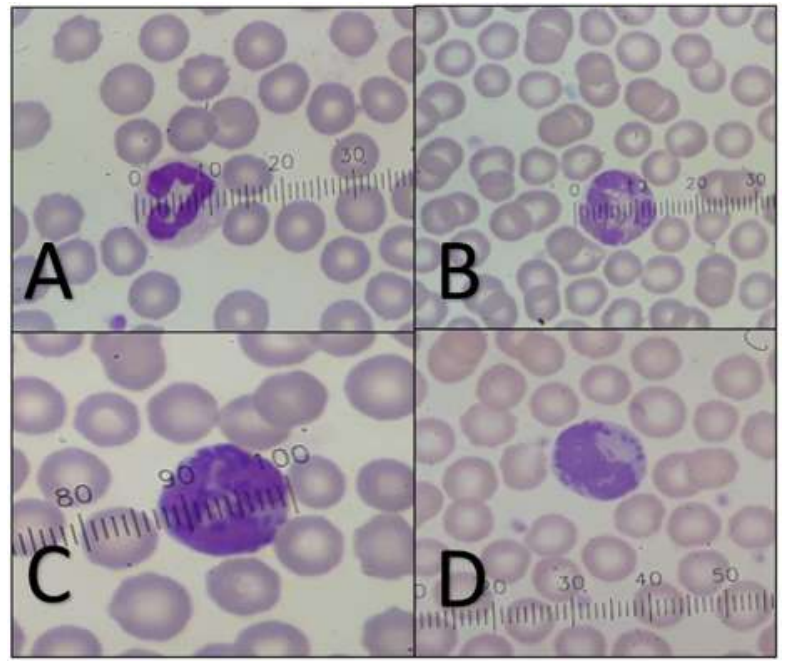

Figure 3. Size of PMs. A) A lobulated PM neutrophil with a clear cytoplasm with small granules and approximate size of 13 microns. B) A lobulated PM eosinophil with pink granules and approximate size of 13 microns. C) and D) A PM basophil, with coarse basophilic granules, and approximate size of 14 microns (100X magnification and under the scale). 


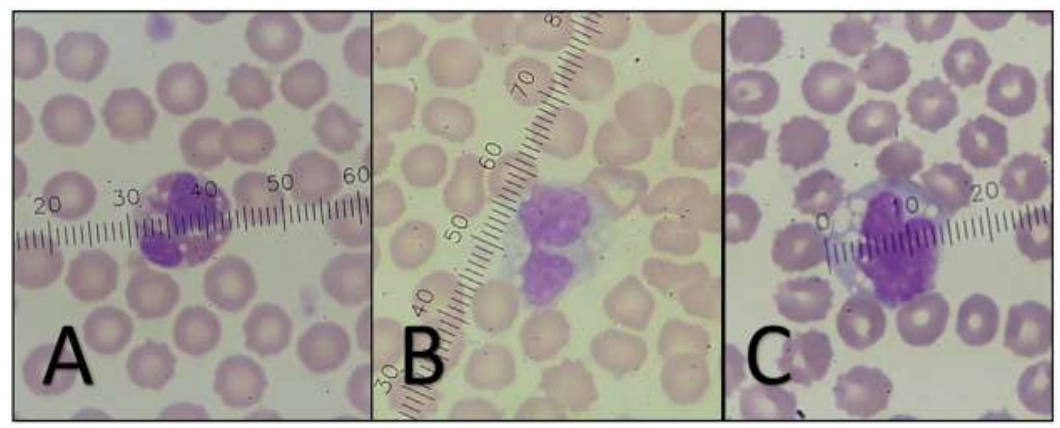

Figure 4. A) A vacuolated PM eosinophil with an approximate size of 13 microns. B) and C) Vacuolated monocytes with abundant basophilic cytoplasm, irregular borders, and an approximate size of 15 microns (100X magnification).

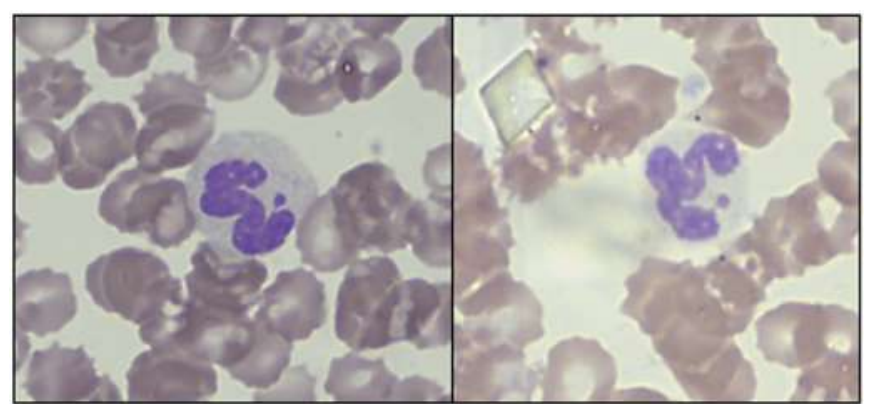

Figure 5. Presence of Barr chromatin in lobulated PM neutrophils (the images were obtained from the thick part of the smears; therefore, they are considered as incidental findings; $100 \mathrm{X}$ magnification).

At the PBS of $16 \mathrm{dogs}$, a circulating (Figure 6A); and the presence of apoptotic cells erythroblast was found as an occasional was observed in samples from 10 dogs (Figure finding outside the count of 100 leukocytes 6B).

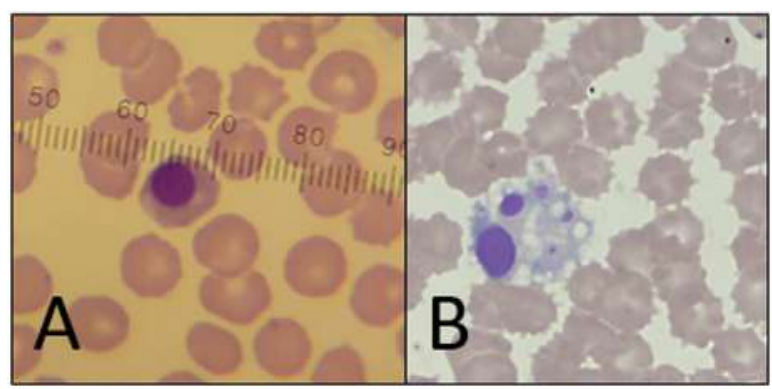

Figure 6. A) Presence of orthochromatic erythroblast, with an average size of 7 microns (not included in the differential due to its low presence; therefore, not considered for the statistical analyzes). B) Presence of apoptotic cells (the image was obtained from the thick part of the smear; consequently, it was considered as an incidental finding; 100X magnification).

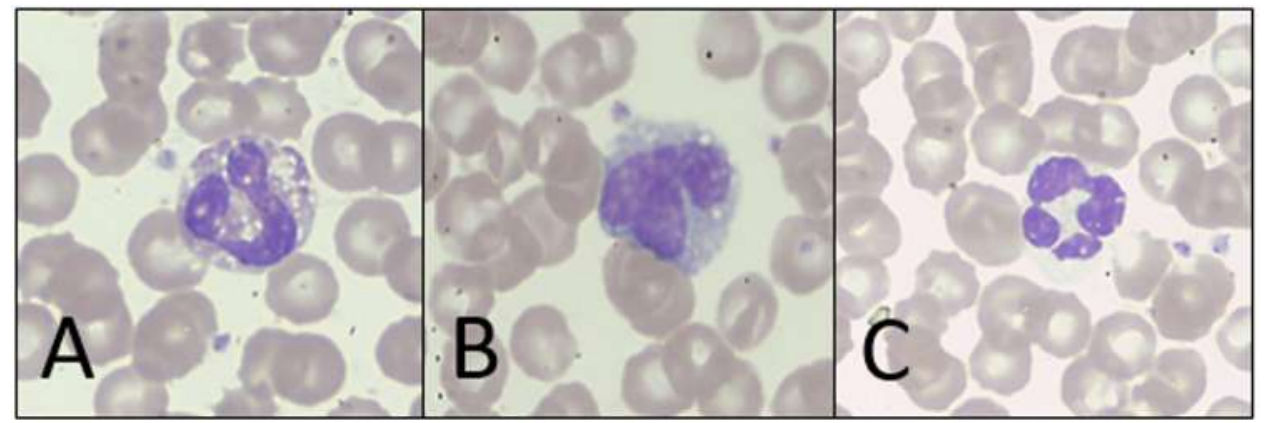

Figure 7. A) Eosinophil with cytoplasmic vacuoles. B) Monocyte with cleft nucleus and basophilic cytoplasm. C) PM neutrophil with four lobes. 
Table 3 describes the measures of central tendency and dispersion for the $\mathrm{CBC}$ quantitative data, detailed by breed, sex, and age of the study population. Table 4 describes the measures of central tendency in the absolute value of the differential of leukocytes and PLT of the dogs included in the study, according to breed, sex, and age. Breeds with only one individual was not included in the analysis (i.e., Akita, Beagle, Bull terrier, Weimaraner). Non-interpretable data on reactive lymphocytes and PMs basophils were not included in the table, considering that the CIs for the samples of such individuals presented great amplitudes because the sample size of the subgroup was deemed to be low.

Statistical tests for normality estimation to determine the BIs were performed. The medium-size breeds (i.e., Beagle, Bull terrier, Basset hound) were excluded from the study population, looking for greater uniformity of the known factors. These tests were then applied to the results of 141 dogs, without discernment by sex or age, and are detailed according to data distribution in Tables 5 and 6.

\section{Discussion}

We aimed to propose base-line information for a correct definition of BRIs to the CBC in the Colombian dog population regarding the potential variability of the individuals, according to breed, sex, and age. A total of 146 CBC records obtained from healthy donor dogs of a blood-bank in Medellín (Colombia) and its corresponding PBS were analyzed. In addition, we provided information on the morphological characteristics of the hematopoietic cells in dogs.

The study's blood-bank establishes an HTC $>40 \%$ to define the different hematic components from the canine donors as acceptable. However, previous studies have reported an HTC ranging from 37 to $52 \%$ in clinically normal dogs, being influenced by several factors such as demographic conditions, age, sex, and breed. Therefore, the HTC value is not a decisive factor per se when declaring a dog as healthy or sick. Its estimate must be accompanied by a complete clinical examination and a correct anamnesis (Campora et al., 2011; Jangsangthong, 2012).

The evaluation of morphological characteristics has relevance in the clinical setting nowadays. In the case of RBCs, alterations in size (anisocytosis) and shape (poikilocytosis) may occur, and their identification is an important issue in certain pathologies (Villiers and Blackwook, 2009). In the present study, the size of hematopoietic cells according to sex, age, and breed was within limits established by the literature for the three cell-lines (Villiers and Blackwook, 2009). No differences were found for the other morphological characteristics.

Reticulocytes contain a low amount of hemoglobin and are part of erythroid maturation before the nucleus is expelled. They remain in the bone marrow for 24 to 48 hours before released into circulation. Reticulocytes contain numerous RNA aggregates, revealed by Brilliant cresyl-blue stain, showing a polychromatophilic color when Wright's stain is applied (Villiers and Blackwook, 2009). We did not find polychromatophilia on the PBS, which indicates that dogs were not undergoing any detectable process of medullar regeneration at the time of sampling, contributing to the definition of the dog as healthy. This data was contrasted with the veterinary clinical laboratory report, where reticulocyte count was always $\leq 1$ (data not shown).

Monocytes cytoplasmic vacuoles were found - as it has been reported (Villiers and Blackwook, 2009), described as a fine powder and pink granules, not being associated with any pathological process in dogs (CampuzanoMaya, 2008; Grandía et al., 2019). Cytoplasmic vacuoles were also found in PMs eosinophils from the only Weimaraner in the study, presenting 14 vacuolated PMs eosinophils. This finding may be casual or an unknown feature of the breed. No related information was found in the literature. 
Table 3. Measures of central tendency from erythrogram and total leukocytes count of a healthy dog population, donors of a blood-bank in Medellín (Colombia) by breed, sex, and age $(\mathrm{n}=146)$.

\begin{tabular}{|c|c|c|c|c|c|c|c|c|c|c|c|c|c|c|c|c|c|}
\hline \multirow{3}{*}{ Breed } & \multirow{3}{*}{$\mathbf{n}$} & \multicolumn{4}{|c|}{ Red blood cell count $\left(\times 10^{6} / \mu \mathrm{L}\right)$} & \multicolumn{4}{|c|}{ Hemoglobin (g/dL) } & \multicolumn{4}{|c|}{ Hematocrit (\%) } & \multicolumn{4}{|c|}{ Mean corpuscular volume (fL) } \\
\hline & & \multirow[t]{2}{*}{ Mean } & \multirow[t]{2}{*}{ SD } & \multicolumn{2}{|c|}{$95 \% \mathrm{CI}$} & \multirow[t]{2}{*}{ Mean } & \multirow[t]{2}{*}{ SDC } & \multicolumn{2}{|c|}{$95 \% \mathrm{CI}$} & \multirow[t]{2}{*}{ Mean } & \multirow[t]{2}{*}{ SDC } & \multicolumn{2}{|c|}{$95 \% \mathrm{CI}$} & \multirow[t]{2}{*}{ Mean } & \multirow[t]{2}{*}{ SDC } & \multicolumn{2}{|c|}{$95 \%$ CI } \\
\hline & & & & Min & Max & & & Min & Max & & & Min & Max & & & Min & Max \\
\hline Cross-breed & 34 & 6.99 & 0.65 & 6.76 & 7.21 & 16.43 & 1.41 & 15.93 & 16.92 & 48.74 & 3.74 & 47.43 & 50.04 & 69.93 & 2.95 & 68.91 & 70.96 \\
\hline Pitbull & 23 & 6.96 & 0.56 & 6.72 & 7.2 & 16.6 & 1.29 & 16.04 & 17.16 & 49.77 & 3.24 & 48.37 & 51.17 & 71.63 & 2.65 & 70.48 & 72.77 \\
\hline Golden retriever & 22 & 6.6 & 0.62 & 6.32 & 6.87 & 15.97 & 1.07 & 15.49 & 16.44 & 47.47 & 3.34 & 45.99 & 48.95 & 72.19 & 3.51 & 70.63 & 73.74 \\
\hline Labrador retriever & 18 & 6.61 & 0.76 & 6.23 & 6.99 & 15.82 & 1.33 & 15.15 & 16.48 & 46.7 & 4.74 & 44.34 & 49.06 & 70.77 & 2.61 & 69.47 & 72.06 \\
\hline Rottweiler & 16 & 6.48 & 0.57 & 6.18 & 6.79 & 14.72 & 1.04 & 14.16 & 15.27 & 43.68 & 3.19 & 41.98 & 45.37 & 67.1 & 1.39 & 66.36 & 67.84 \\
\hline German shepherd & 10 & 6.94 & 0.5 & 6.58 & 7.29 & 16.3 & 1.47 & 15.25 & 17.35 & 47.72 & 3.79 & 45.01 & 50.43 & 68.82 & 2.67 & 66.91 & 70.73 \\
\hline Siberian husky & 8 & 7.49 & 0.55 & 7.03 & 7.95 & 17.51 & 1.39 & 16.35 & 18.67 & 51.95 & 4.03 & 48.58 & 55.32 & 69.35 & 1.32 & 68.25 & 70.45 \\
\hline Basset hound* & 3 & 6.94 & 0.29 & 6.22 & 7.66 & 15.47 & 0.25 & 14.84 & 16.09 & 46.9 & 1.14 & 44.08 & 49.72 & 67.59 & 1.86 & 62.97 & 72.22 \\
\hline Boxer* & 3 & 6.9 & 0.57 & 5.49 & 8.3 & 16.2 & 1.64 & 12.13 & 20.27 & 48.83 & 3.31 & 40.62 & 57.05 & 70.91 & 3.42 & 62.42 & 79.39 \\
\hline Great Dane* & 3 & 6.16 & 0.68 & 4.48 & 7.84 & 14.63 & 1.55 & 10.78 & 18.48 & 42.6 & 4.25 & 32.05 & 53.15 & 69.19 & 1.54 & 65.37 & 73.01 \\
\hline Rhodesian ridgeback* & 2 & 6.44 & 0.9 & $0 *$ & 14.5 & 15.25 & 1.34 & 3.18 & 27.32 & 46.4 & 6.51 & 0,00 & 104.85 & 72.11 & 0.05 & 71.66 & 72.55 \\
\hline \multicolumn{18}{|l|}{ Sex } \\
\hline Male & 81 & 6.74 & 0.72 & 6.58 & 6.9 & 15.95 & 1.51 & 15.62 & 16.29 & 47.29 & 4.31 & 46.34 & 48.24 & 70.27 & 3.08 & 69.59 & 70.95 \\
\hline Female & 65 & 6.93 & 0.55 & 6.79 & 7.06 & 16.27 & 1.25 & 15.96 & 16.58 & 48.53 & 3.84 & 47.57 & 49.48 & 70.08 & 3,00 & 69.34 & 70.83 \\
\hline \multicolumn{18}{|l|}{ Age (in years) } \\
\hline 1 & 18 & 6.63 & 0.67 & 6.3 & 6.97 & 15.86 & 1.26 & 15.23 & 16.48 & 46.73 & 4.49 & 44.5 & 48.97 & 70.49 & 4.32 & 68.35 & 72.64 \\
\hline 2 & 19 & 6.65 & 0.59 & 6.36 & 6.93 & 15.86 & 1.31 & 15.23 & 16.49 & 47.26 & 3.47 & 45.59 & 48.93 & 71.23 & 3.01 & 69.78 & 72.68 \\
\hline 3 & 30 & 6.89 & 0.5 & 6.7 & 7.08 & 16.34 & 1.21 & 15.89 & 16.79 & 48.47 & 3.17 & 47.28 & 49.65 & 70.44 & 2.49 & 69.51 & 71.37 \\
\hline 4 & 33 & 6.96 & 0.69 & 6.72 & 7.21 & 16.02 & 1.58 & 15.46 & 16.57 & 48.18 & 4.61 & 46.55 & 49.81 & 69.16 & 2.81 & 68.17 & 70.16 \\
\hline 5 & 24 & 6.69 & 0.69 & 6.4 & 6.98 & 15.96 & 1.36 & 15.39 & 16.53 & 47.02 & 4.11 & 45.29 & 48.76 & 70.47 & 3.06 & 69.18 & 71.76 \\
\hline 6 & 12 & 6.99 & 0.74 & 6.52 & 7.46 & 16.56 & 1.69 & 15.48 & 17.63 & 48.48 & 4.93 & 45.35 & 51.62 & 69.35 & 1.97 & 68.09 & 70.6 \\
\hline 7 & 6 & 7.15 & 0.94 & 6.16 & 8.14 & 16.42 & 2,00 & 14.32 & 18.51 & 49.7 & 4.67 & 44.8 & 54.6 & 69.81 & 3.27 & 66.37 & 73.25 \\
\hline 8 & 4 & 6.71 & 0.67 & 5.64 & 7.78 & 15.95 & 1.52 & 13.54 & 18.36 & 48.25 & 5.87 & 38.9 & 57.6 & 71.8 & 3.34 & 66.48 & 77.11 \\
\hline
\end{tabular}


Table 3 continued

\begin{tabular}{|c|c|c|c|c|c|c|c|c|c|c|c|c|}
\hline \multirow{3}{*}{ Breed } & \multicolumn{4}{|c|}{ Medium corpuscular hemoglobin (pg) } & \multicolumn{4}{|c|}{$\begin{array}{l}\text { Mean corpuscular hemoglobin } \\
\text { concentration }(\mathrm{g} / \mathrm{dL})\end{array}$} & \multicolumn{4}{|c|}{ White blood cell count $\left(\times 10^{3} / \mu \mathrm{L}\right)$} \\
\hline & \multirow[t]{2}{*}{ Mean } & \multirow[t]{2}{*}{ SD } & \multicolumn{2}{|c|}{ 95\% CI } & \multirow[t]{2}{*}{ Mean } & \multirow[t]{2}{*}{ SDC } & \multicolumn{2}{|c|}{$95 \% \mathrm{CI}$} & \multirow[t]{2}{*}{ Mean } & \multirow[t]{2}{*}{ SDC } & \multicolumn{2}{|c|}{$95 \% \mathrm{CI}$} \\
\hline & & & Min & Max & & & Min & Max & & & Min & Max \\
\hline Cross-breed & 23.55 & 1.15 & 23.15 & 23.95 & 33.68 & 1.01 & 33.32 & 34.03 & 11.6 & 2.58 & 10.7 & 12.5 \\
\hline Pitbull & 23.87 & 0.93 & 23.47 & 24.27 & 33.47 & 1.45 & 32.85 & 34.1 & 11.12 & 2.33 & 10.11 & 12.13 \\
\hline Golden retriever & 24.32 & 1.68 & 23.57 & 25.06 & 33.68 & 1.46 & 33.04 & 34.33 & 10.64 & 1.82 & 9.84 & 11.45 \\
\hline Labrador retriever & 24.06 & 1.39 & 23.37 & 24.74 & 33.99 & 1.52 & 33.24 & 34.75 & 10.01 & 2.94 & 8.55 & 11.47 \\
\hline Rottweiler & 22.75 & 0.9 & 22.27 & 23.23 & 33.9 & 1.14 & 33.29 & 34.51 & 12.77 & 2.09 & 11.66 & 13.89 \\
\hline German shepherd & 23.54 & 1.76 & 22.27 & 24.8 & 34.16 & 1.55 & 33.05 & 35.27 & 14.13 & 4,00 & 11.26 & 17,00 \\
\hline Siberian husky & 23.38 & 0.85 & 22.67 & 24.09 & 33.72 & 0.95 & 32.92 & 34.51 & 12.51 & 3.86 & 9.28 & 15.74 \\
\hline Basset hound* & 22.29 & 0.6 & 20.8 & 23.79 & 32.98 & 0.32 & 32.18 & 33.78 & 13.13 & 1.86 & 8.51 & 17.74 \\
\hline Boxer* & 23.5 & 1.72 & 19.23 & 27.76 & 33.13 & 1.22 & 30.1 & 36.15 & 14.73 & 0.9 & 12.5 & 16.95 \\
\hline Great Dane* & 23.78 & 0.11 & 23.5 & 24.05 & 34.37 & 0.81 & 32.37 & 36.38 & 10.03 & 2.14 & 4.72 & 15.35 \\
\hline Rhodesian ridgeback* & 23.79 & 1.24 & 12.67 & 34.9 & 32.99 & 1.73 & 17.42 & 48.55 & 11.7 & 0.99 & 2.8 & 20.59 \\
\hline \multicolumn{13}{|l|}{ Sex } \\
\hline Male & 23.73 & 1.35 & 23.43 & 24.03 & 33.77 & 1.24 & 33.49 & 34.04 & 11.68 & 2.76 & 11.07 & 12.29 \\
\hline Female & 23.53 & 1.26 & 23.22 & 23.84 & 33.62 & 1.3 & 33.3 & 33.94 & 11.57 & 2.78 & 10.88 & 12.26 \\
\hline \multicolumn{13}{|l|}{ Age (in years) } \\
\hline 1 & 23.99 & 1.52 & 23.23 & 24.75 & 34.05 & 1.3 & 33.4 & 34.69 & 13.86 & 2.5 & 12.62 & 15.11 \\
\hline 2 & 23.91 & 1.4 & 23.24 & 24.59 & 33.73 & 1.48 & 33.01 & 34.44 & 11.15 & 2.02 & 10.18 & 12.13 \\
\hline 3 & 23.75 & 1.02 & 23.36 & 24.13 & 33.72 & 1.15 & 33.29 & 34.15 & 12.21 & 2.77 & 11.17 & 13.25 \\
\hline 4 & 23.04 & 1.24 & 22.6 & 23.48 & 33.31 & 1.04 & 32.94 & 33.68 & 10.6 & 2.45 & 9.73 & 11.47 \\
\hline 5 & 23.95 & 1.47 & 23.33 & 24.57 & 33.98 & 1.23 & 33.46 & 34.5 & 11.27 & 2.24 & 10.33 & 12.22 \\
\hline 6 & 23.69 & 1.03 & 23.03 & 24.34 & 34.15 & 0.9 & 33.58 & 34.73 & 12.27 & 3.69 & 9.92 & 14.61 \\
\hline 7 & 23.01 & 1.1 & 21.86 & 24.16 & 33,00 & 1.69 & 31.23 & 34.77 & 10.08 & 3.41 & 6.5 & 13.66 \\
\hline 8 & 23.81 & 1.44 & 21.51 & 26.1 & 33.2 & 2.32 & 29.5 & 36.89 & 10.53 & 2.68 & 6.27 & 14.78 \\
\hline
\end{tabular}

Non-interpretable data; SD: Standard deviation; CI: Confidence interval. 


\begin{tabular}{|c|c|c|c|c|c|c|c|c|c|c|c|c|}
\hline \multirow{3}{*}{ Breed } & \multicolumn{4}{|c|}{ PMs neutrophils $\left(\times 10^{3} / \mu \mathrm{L}\right)$} & \multicolumn{4}{|c|}{ PMs eosinophils $\left(\times 10^{3} / \mu \mathrm{L}\right)$} & \multicolumn{4}{|c|}{ Lymphocytes $\left(\times 10^{3} / \mu \mathrm{L}\right)$} \\
\hline & \multirow[t]{2}{*}{ Mean } & \multirow[t]{2}{*}{ SD } & \multicolumn{2}{|c|}{$95 \%$ CI } & \multirow[t]{2}{*}{ Mean } & \multirow[t]{2}{*}{ SD } & \multicolumn{2}{|c|}{$95 \%$ CI } & \multirow[t]{2}{*}{ Mean } & \multirow[t]{2}{*}{ SD } & \multicolumn{2}{|c|}{$95 \%$ CI } \\
\hline & & & Min & Max & & & Min & Max & & & Min & Max \\
\hline Cross-breed & 7.07 & 1.86 & 6.42 & 7.71 & 1.35 & 0.86 & 1.05 & 1.65 & 2.58 & 1.06 & 2.21 & 2.95 \\
\hline Pitbull & 7.14 & 1.94 & 6.3 & 7.98 & 1.03 & 0.67 & 0.74 & 1.32 & 2.37 & 0.93 & 1.96 & 2.77 \\
\hline Golden retriever & 7.09 & 1.95 & 6.22 & 7.95 & 0.59 & 0.32 & 0.45 & 0.73 & 2.44 & 0.82 & 2.07 & 2.8 \\
\hline Labrador retriever & 5.93 & 2,00 & 4.94 & 6.92 & 1.21 & 0.67 & 0.88 & 1.55 & 2.2 & 1.16 & 1.63 & 2.78 \\
\hline Rottweiler & 7.23 & 1.85 & 6.25 & 8.21 & 2.1 & 0.71 & 1.73 & 2.48 & 2.66 & 0.86 & 2.2 & 3.12 \\
\hline German shepherd & 8.41 & 3.04 & 6.23 & 10.58 & 2.03 & 1.31 & 1.09 & 2.97 & 2.74 & 1.4 & 1.74 & 3.74 \\
\hline Siberian husky & 7.76 & 3.03 & 5.22 & 10.28 & 1.29 & 0.97 & 0.48 & 2.1 & 2.84 & 1.57 & 1.53 & 4.15 \\
\hline Basset hound* & 8.09 & 1.14 & 5.25 & 10.93 & 2.22 & 0.83 & 0.17 & 4.28 & 1.95 & 0.5 & 0.72 & 3.19 \\
\hline Boxer* & 8.70 & 1.07 & 6.06 & 11.35 & 1.99 & 0.56 & 0.6 & 3.37 & 2.73 & 0.4 & 1.75 & 3.72 \\
\hline Great Dane* & 5.79 & 1.62 & 1.77 & 9.82 & 0.93 & 0.27 & 0.26 & 1.6 & 2.69 & 0.82 & 0.64 & 4.74 \\
\hline Rhodesian ridgeback* & 7.48 & 0.47 & 3.28 & 11.68 & 1.53 & 0.29 & 0,00 & 4.17 & 2.1 & 0.01 & 1.98 & 2.21 \\
\hline \multicolumn{13}{|l|}{ Sex } \\
\hline Male & 7.12 & 2.19 & 6.64 & 7.61 & 1.30 & 0.84 & 1.12 & 1.49 & 2.58 & 1.02 & 2.35 & 2.80 \\
\hline Female & 7.15 & 1.92 & 6.67 & 7.62 & 1.33 & 0.92 & 1.10 & 1.56 & 2.42 & 1.03 & 2.17 & 2.68 \\
\hline \multicolumn{13}{|l|}{ Age (in years) } \\
\hline 1 & 8.38 & 2.14 & 7.31 & 9.44 & 1.72 & 1.16 & 1.14 & 2.29 & 2.98 & 1.17 & 2.4 & 3.56 \\
\hline 2 & 6.68 & 1.57 & 5.92 & 7.43 & 0.97 & 0.64 & 0.67 & 1.28 & 2.92 & 1.13 & 2.38 & 3.47 \\
\hline 3 & 7.51 & 2.29 & 6.66 & 8.37 & 1.36 & 0.88 & 1.03 & 1.69 & 2.63 & 0.92 & 2.29 & 2.98 \\
\hline 4 & 6.49 & 1.67 & 5.9 & 7.09 & 1.37 & 0.86 & 1.06 & 1.67 & 2.17 & 0.88 & 1.86 & 2.48 \\
\hline 5 & 6.76 & 1.91 & 5.95 & 7.56 & 1.41 & 0.82 & 1.07 & 1.76 & 2.37 & 0.79 & 2.04 & 2.71 \\
\hline 6 & 7.71 & 2.35 & 6.21 & 9.2 & 1.3 & 0.89 & 0.73 & 1.87 & 2.51 & 1.37 & 1.63 & 3.38 \\
\hline 7 & 7.12 & 2.98 & 3.99 & 10.25 & 0.71 & 0.43 & 0.26 & 1.17 & 1.64 & 0.42 & 1.21 & 2.08 \\
\hline 8 & 6.7 & 1.73 & 3.95 & 9.46 & 0.78 & 0.52 & 0,00 & 1.6 & 2.41 & 1.18 & 0.53 & 4.3 \\
\hline
\end{tabular}


Table 4 continued

\begin{tabular}{|c|c|c|c|c|c|c|c|c|c|c|c|c|}
\hline \multirow{3}{*}{ Breed } & \multicolumn{4}{|c|}{ Medium corpuscular hemoglobin (pg) } & \multicolumn{4}{|c|}{$\begin{array}{l}\text { Mean corpuscular hemoglobin } \\
\text { concentration }(\mathrm{g} / \mathrm{dL})\end{array}$} & \multicolumn{4}{|c|}{ White blood cell count $\left(\times 10^{3} / \mu \mathrm{L}\right)$} \\
\hline & \multirow[t]{2}{*}{ Mean } & \multirow[t]{2}{*}{ SD } & \multicolumn{2}{|c|}{$95 \% \mathrm{CI}$} & \multirow[t]{2}{*}{ Mean } & \multirow[t]{2}{*}{ SDC } & \multicolumn{2}{|c|}{$95 \% \mathrm{CI}$} & \multirow[t]{2}{*}{ Mean } & \multirow[t]{2}{*}{ SDC } & \multicolumn{2}{|c|}{$95 \%$ CI } \\
\hline & & & Min & Max & & & Min & Max & & & Min & Max \\
\hline Cross-breed & 0.58 & 0.37 & 0.45 & 0.71 & 333.67 & 59.56 & 312.89 & 354.46 & 8.31 & 0.6 & 8.09 & 8.52 \\
\hline Pitbull & 0.56 & 0.28 & 0.44 & 0.68 & 341.86 & 48.13 & 321.05 & 362.68 & 8.49 & 0.62 & 8.22 & 8.75 \\
\hline Golden retriever & 0.49 & 0.25 & 0.38 & 0.6 & 307.45 & 43.04 & 288.37 & 326.53 & 8.48 & 0.57 & 8.22 & 8.74 \\
\hline Labrador retriever & 0.53 & 0.28 & 0.39 & 0.67 & 345.16 & 44.1 & 323.23 & 367.1 & 7.92 & 0.51 & 7.67 & 8.18 \\
\hline Rottweiler & 0.69 & 0.39 & 0.49 & 0.9 & 376.06 & 76.08 & 335.52 & 416.6 & 7.5 & 0.41 & 7.27 & 7.72 \\
\hline German shepherd & 0.82 & 0.49 & 0.47 & 1.18 & 329.3 & 73.98 & 276.37 & 382.22 & 8.81 & 0.52 & 8.43 & 9.18 \\
\hline Siberian husky & 0.61 & 0.36 & 0.31 & 0.91 & 297.13 & 39.89 & 263.78 & 330.47 & 8.99 & 0.48 & 8.59 & 9.39 \\
\hline Basset hound* & 0.67 & 0.34 & 0,00 & 1.52 & 274.66 & 108.02 & 6.31 & 543.01 & 8.26 & 0.3 & 7.5 & 9.02 \\
\hline Boxer* & 1.26 & 0.89 & 0,00 & 3.46 & 332.33 & 40.69 & 231.23 & 433.43 & 8.43 & 0.11 & 8.14 & 8.72 \\
\hline Great Dane* & 0.59 & 0.05 & 0.47 & 0.71 & 266.67 & 65.5 & 103.95 & 429.38 & 8.3 & 0.75 & 6.42 & 10.18 \\
\hline Rhodesian ridgeback* & 0.41 & 0.12 & 0,00 & 1.47 & 300.5 & 12.02 & 192.49 & 408.5 & 8.25 & 0.07 & 7.61 & 8.88 \\
\hline \multicolumn{13}{|l|}{ Sex } \\
\hline Male & 0.62 & 0.36 & 0.54 & 0.7 & 329.27 & 58.05 & 316.44 & 342.11 & 8.32 & 0.68 & 8.17 & 8.47 \\
\hline Female & 0.59 & 0.37 & 0.5 & 0.68 & 335.58 & 61.51 & 320.34 & 350.83 & 8.29 & 0.62 & 8.14 & 8.44 \\
\hline \multicolumn{13}{|l|}{ Age (in years) } \\
\hline 1 & 0.75 & 0.5 & 0.5 & 1,00 & 318.44 & 45.35 & 295.89 & 341,00 & 8.22 & 0.92 & 7.76 & 8.68 \\
\hline 2 & 0.55 & 0.26 & 0.43 & 0.68 & 329.68 & 64.29 & 298.7 & 360.67 & 8.28 & 0.67 & 7.96 & 8.61 \\
\hline 3 & 0.65 & 0.39 & 0.51 & 0.8 & 319.27 & 51.91 & 299.88 & 338.65 & 8.5 & 0.55 & 8.3 & 8.71 \\
\hline 4 & 0.5 & 0.24 & 0.42 & 0.59 & 359.94 & 61.74 & 338.05 & 381.83 & 8.19 & 0.67 & 7.95 & 8.43 \\
\hline 5 & 0.6 & 0.4 & 0.43 & 0.77 & 318.33 & 74.19 & 287.01 & 349.66 & 8.2 & 0.5 & 7.99 & 8.41 \\
\hline 6 & 0.7 & 0.32 & 0.5 & 0.91 & 333.83 & 35.8 & 311.08 & 311.08 & 8.57 & 0.62 & 8.17 & 8.96 \\
\hline 7 & 0.56 & 0.47 & 0.07 & 1.05 & 346.33 & 53.63 & 290.05 & 402.62 & 8.22 & 0.68 & 7.5 & 8.93 \\
\hline 8 & 0.61 & 0.42 & 0,00 & 1.27 & 327,00 & 53.99 & 241.09 & 412.91 & 8.2 & 0.45 & 7.48 & 8.92 \\
\hline
\end{tabular}

*Non-interpretable data; SD: Standard deviation; CI: Confidence interval. 
The presence of cytoplasmic granulations in leukocytes was observed as secondary granules, as indicated in the literature (Villiers and Blackwook, 2009). It should be noted that the size of the small granules of PMs neutrophils was not visible under the light microscope. Likewise, the size of the granules inside the PMs eosinophils was considerable, reaching up to $2 \mu \mathrm{m}$.

The appendix, known as Barr chromatin found in PMs, has a shape similar to a drumstick inside PMs neutrophils. The same was found in both females and males in the present study. Lashari et al. (2018) conducted a comparative study in humans and canines, concluding that such an appendix is more frequently found in females than males in both populations. Similar findings have been reported elsewhere (Chaterjee, 2014; Barjatiya et al., 2016). Probably, other inclusions were not observed because all samples were obtained from healthy dogs.

Our CBC results did not show sex-related differences, probably because the population consisted exclusively of adults -1 to 8 years-old. Conversely, a study conducted with 132 dog breeds in France showed BRIs differences by sex and age of the animals (Geffré et al., 2011). Likewise, Pedrozo et al. (2010) found - in apparently healthy dogs from Asunción (Paraguay)- that WBC and PMs neutrophils and lymphocytes decreased significantly as the age of the animal increased.
Siberian husky dogs $(\mathrm{n}=8)$ showed high RBC, HB, and HTC values. This could be explained by the origin of the native breed (Chukchi Peninsula, located in the NorthEastern end of Siberia, Russia), physiologically adapted to high altitude ( $>3,000$ masl) hypoxia by increased erythropoietin secretion. This is an important observation because these findings could be confused with haemoconcentration or dehydration. It is known that breeds such as Miniature poodle, German shepherd, Boxer, and Chihuahua can present high HTC not associated with any pathological condition (Stockham and Scott, 2008). In the present study, this parameter was analyzed in Boxer and German shepherd samples, but the values obtained were very similar to the other breeds.

Lavoué et al. (2014) conducted a study in France and Belgium to determine Dogue de Bordeaux breed-specific hematological BRIs, as this breed is genetically predisposed to juvenile glomerulonephropathy and hypothyroidism. They reported that this breed presented the highest BRIs for HB, HTC, MCV, MCHC, and MVP compared to other breeds. Although no dogs of this breed were included in our study, the above information indicates that the data obtained can be specific to this breed and geographical region.

Table 6. Biological intervals (BIs) for parameters not

Table 5. Biological intervals for normally distributed parameters in cellular blood counts (CBC) from healthy large and giant-breed dogs of the study population $(n=141)$.

\begin{tabular}{lccccccc}
\hline \multirow{2}{*}{ Parameter } & \multicolumn{3}{c}{ 95\% CI } & KS significance & \multicolumn{2}{c}{ Biological interval } \\
\cline { 2 - 8 } & Mean & SD & Lower limit & Upper limit & & Min & Max \\
\hline Hemoglobin $(g / d L)$ & 16.12 & 1.41 & 15.89 & 16.36 & $0.200^{*}$ & 13.30 & 18.95 \\
Hematocrit $(\%)$ & 47.91 & 4.12 & 47.22 & 48.61 & $0.200^{*}$ & 39.67 & 56.16 \\
MCV $(f L)$ & 70.27 & 3.08 & 69.75 & 70.79 & 0.071 & 64.11 & 76.43 \\
MCH $(p g)$ & 23.67 & 1.33 & 23.45 & 23.90 & $0.200^{*}$ & 21.02 & 26.33 \\
MCHC $(\mathrm{g} / \mathrm{dL})$ & 33.69 & 1.24 & 33.48 & 33.90 & $0.200^{*}$ & 31.21 & 36.17 \\
Platelet count $\left(10^{3} / \mu L\right)$ & 334.97 & 57.69 & 325.26 & 344.68 & $0.200^{*}$ & 219.59 & 450.35 \\
MPV $(f L)$ & 8.31 & 0.66 & 8.20 & 8.42 & $0.200^{*}$ & 6.98 & 9.63 \\
WBC $\left(10^{3} / \mu L\right)$ & 11.60 & 2.79 & 11.13 & 12.07 & $0.200^{*}$ & 6.02 & 17.18 \\
\hline
\end{tabular}

KS: Kolmogorov-Smirnov with correction of Lilliefors (significance level: $\mathrm{p}>0.05$ ). *Lower limit of true significance. MCV: Mean corpuscular volume; MCH: Medium corpuscular hemoglobin; MCHC: Mean corpuscular hemoglobin concentration; MPV: Mean platelet volume; WBC: White blood cell count; PMs: Polymorphonuclears (absolute values). 
normally-distributed in cellular blood counts (CBC) from healthy large and giant-breed dogs of the study population $(\mathrm{n}=141)$.

\begin{tabular}{lccc}
\hline Parameter & \multicolumn{2}{c}{ Percentiles } & KS \\
\cline { 2 - 4 } & $\mathbf{2 . 5}^{\text {th }}$ & $\mathbf{9 7 . 5}^{\text {th }}$ & Significance \\
\hline RBC $\left(10^{6} / \mu L\right)$ & 5.49 & 7.98 & 0.02 \\
PMs eosinophils $\left(10^{3} / \mu L\right)$ & 0.16 & 3.18 & 0.00 \\
PMs monocytes $\left(10^{3} / \mu L\right)$ & 0.11 & 1.56 & 0.00 \\
PMs basophils $\left(10^{3} / \mu L\right)$ & 0.00 & 0.26 & 0.00 \\
Reactive lymphocytes & 0.00 & 0.29 & 0.00 \\
$\left(10^{3} / \mu L\right)$ & & & \\
Platelet count $\left(10^{3} / \mu L\right)$ & 334.97 & 57.69 & 325.26 \\
MPV $(f L)$ & 8.31 & 0.66 & 8.20 \\
WBC $\left(10^{3} / \mu L\right)$ & 11.60 & 2.79 & 11.13 \\
\hline
\end{tabular}

KS: Kolmogorov-Smirnov with correction of Lilliefors (significance level: $\mathrm{p}>0.05$ ). RBC: Red blood cells count; PMs: Polymorphonuclears (absolute values).

Regarding $\mathrm{MCV}, \mathrm{MCH}$, and $\mathrm{MCHC}$ results, no differences were found among breed. However, increased $\mathrm{MCV}$ has been physiologically observed in breeds such as Miniature Poodle and Dogue de Bordeaux (Thrall, 2012; Lavoué et al., 2014) without any health-related implications. Likewise, a decrease in MCV has been observed in breeds such as Chow-Chow, Shar-Pei, and Akita (Thrall, 2012). In our study, this parameter was analyzed only in Akita samples, and the values were very similar to the other breeds.

We found high WBC in samples from Boxer dogs $\left(14.73 \times 10^{3} / \mu \mathrm{L}\right)$, similar to that reported by Pedrozo et al. (2010), who described higher WBC in large breeds than in small dog breeds. Conversely, Gommeren et al. (2006) found lower WBC, reported as physiological, in Belgian shepherd dogs, considered a large breed.

Specific leukocyte populations could be physiologically increased in healthy dogs of certain breeds (Mesa, 2015). In the present study, German shepherd and Boxer dogs presented the highest PMs neutrophils counts, whereas the counts were lower in Great Danes and Labrador retriever. Rottweiler and German shepherd showed the highest PMs eosinophils counts, which agrees with the literature where breeds such as the Bernese Mountain Dog, German shepherd, and Rottweiler presented higher PMs eosinophils count compared to the general canine population (Lilliehook and Tvedten, 2003; Nielsen et al., 2009). Likewise, Geffré et al. (2011) found that PMs eosinophils counts were higher in Brittany Spaniel, Rottweiler, and German shepherd than in the general population. In our study, lymphocytes and monocytes counts were similar among breeds and some reactive lymphocytes and PMs, basophils were found in very low counts.

Thrombocytopenia may indicate decreased production, immune-mediated destruction, excessive consumption, non-immune-mediated destruction, splenic sequestration, or pseudothrombocytopenia by platelet aggregates (Stockham and Scott, 2008). Physiological thrombocytopenia has been observed in Cavalier King Charles breed and in Dogue de Bordeaux, which present breed-specific asymptomatic macro-thrombocytopenia (Smedile et al., 1997; Pedersen et al., 2002; Singh and Lamb, 2005; Bertazzolo et al., 2007; Lavoué et al., 2014). In the present study, the parameters evaluated in the plaquetogram did not show variation among breeds.

The estimation of BIs is an optimal approach to provide basic information, which can later be considered in designing methodologies aiming to establish robust BRIs. To estimate BIs in healthy large and giant-breed dogs, we excluded five individuals who corresponded to mediumsize breeds (by definition, weights between 10$25 \mathrm{Kg}$, height $>50 \mathrm{~cm}$; Pedrozo et al., 2010).

In our study, the estimated BIs for the RBC, $\mathrm{HB}$, and HTC showed negligible variation compared to the published reports in Colombia. Bossa et al. (2012) reported values of $5.27-9.12 \times 10^{6} / \mu \mathrm{L}, \quad 13.46-22.31 \mathrm{~g} / \mathrm{dL}$, and 40.01-65.60\%, for RBC, HB, and HTC, respectively, in samples collected in Medellín (Antioquia province). However, Merizalde (2011) reported similar values to the ones found herein $\left(5.16-11.20 \times 10^{6} / \mu \mathrm{L}, 11.80\right.$ $25.30 \mathrm{~g} / \mathrm{dL}$, and $37.00-67.91 \%$, for RBC, HB, and HTC, respectively) in samples collected 
in Bogotá (Cundinamarca province). In that report, more variations were expected in terms of these parameters, considering that dogs at high altitude have higher RBC, HB, and HTC than those located at lower altitude.

In the present study, $\mathrm{MCV}, \mathrm{MCH}$, and $\mathrm{MCHC}$ were increased compared to the BRIs established by Merizalde (2011) in Bogotá (49.50-87.10 fL, $16.90-27.20 \mathrm{pg}$, and $28.80-42.60 \mathrm{~g} / \mathrm{dL}$, respectively), but are similar to values reported by Bossa et al. (2012) in Medellín (62.0-82.3 fL, 21.3-8.2 pg, and 31.2-37.5 g/dL, respectively).

The lower WBC limit (LL) is similar among both studies conducted so far in Colombia, but the upper limit (UL) varies widely. Merizalde (2011) reported LL of $5.56 \times 10^{3} / \mu \mathrm{L}$ and UL of $29.08 \times 10^{3} / \mu$; meanwhile, Bossa et al. (2012) reported LL of $6.4 \times 10^{3} / \mu \mathrm{L}$ and $\mathrm{UL}$ of $23.7 \times 10^{3} / \mu \mathrm{L}$.

Absolute leukocyte values of the different populations showed that PMs neutrophils presented minimal variations compared to the literature. Geffré et al. (2011) estimated values of $2.9-13.6 \times 10^{3} / \mu \mathrm{L}$, Merizalde (2011) values of 3.38-19.77 $\times 10^{3} / \mu \mathrm{L}$, and Bossa et al. (2012) values of $4.5-19.9 \times 10^{3} / \mu \mathrm{L}$. It has been reported that stress at the time of puncture for blood collection influences the counts, generating neutrophilia (Willard et al., 2004). In the case of PMs eosinophils, lymphocytes, and monocytes, little variation was also observed. According to Willard et al. (2004), the minimum value of monocytes is $0.22 \times 10^{3} / \mu \mathrm{L}$, and for Day et al. (2000), the maximum value is $0.95 \times 10^{3} / \mu \mathrm{L}$. For the PMs eosinophils, the lowest value according to Latimer et al. (2005) is $0.65 \times 10^{3} / \mu \mathrm{L}$, and the highest value according to Day et al. (2000) is $1 \times 10^{3} / \mu \mathrm{L}$. For the reactive lymphocytes and the PMs basophils, the information obtained in the different studies shows very low values, which agrees with the PBS obtained from the dogs evaluated herein. For the PMs basophils, Latimer et al. (2005) reported an average value of $0.07 \times 10^{3} / \mu \mathrm{L}$ and Willard et al. (2004) an average value of $0.28 \times 10^{3} / \mu \mathrm{L}$, being this the highest report. According to the literature, donors should preferably be large and quiet breeds since it facilitates handling and blood extraction, thus avoiding sedation. The breeds used in the present study for the definition of BIs are recurrent donors, thus behaving calm at the moment of sampling, preventing the CBC's parameters from being altered by conditions as stress or to require sedation.

A difference of about 100,000 units to the BRIs for the PLT was observed for both LL and UL, when our results were compared to other studies in the country. Bossa et al. (2012) reported values of $144.4-523 \times 10^{3} / \mu \mathrm{L}$, similar to those estimated by Merilzalde $(2011 ; 142.8$ $512.4 \times 10^{3} / \mu \mathrm{L}$ ).

The MPV was considered a new parameter that relates to platelet size and may depend on the activation of benign or neoplastic processes (Jaramillo and Acevedo, 2010). To the best of our knowledge, only two studies related to this parameter have been reported in the literature, so it is not possible to contrast our findings. However, considering that platelet sizes were normal, we can start from our values for future research approaches and take it into account for clinical interpretation.

Although there is increasing interest in establishing breed-specific BRIs, selecting a homogeneous and representative reference population of each to determine such estimations can be difficult. The American Society for Veterinary Clinical Pathology (ASVCP) promotes the establishment of BRIs by nonparametric methods using at least 120 individuals for each parameter. It is difficult to achieve these sample sizes in clinical practice and, at the same time, guarantee the quality of the data.

Of the population studied, $23.3 \%$ corresponded to cross-breed dogs. This implies that there is a need for detailed research approaches to BIs in this particular dog population, which in turn must be discriminated based on size and predominant breed-type (or tendency). 
With data standardization, considering only dogs of large and giant breeds, this work provides BIs for some of the $\mathrm{CBC}$ findings in Medellin, but it must be verified if there are significant differences between breeds according to dog size, when a broader collection of breeds is considered. Likewise, the process carried out herein highlights the morphological characteristics of hematopoietic cells in healthy canines, such as size, granularity, and inclusions such as cytoplasmic vacuoles in monocytes PMs eosinophils.

The presence of Barr chromatin, with a positive tendency (but not exclusivity) of presentation in bitches, likewise occasional circulating erythroblasts, both considered as normal findings in healthy dogs, lead to a wellestablished approximation to the definition of blood cells alterations that may alert the attending veterinarian to the early diagnosis of benign or neoplastic disease.

It is important to perform a combined interpretation of the findings to the $\mathrm{CBC}$ (quantitative data from automated equipment) and qualitative data (evaluated in the PBS). We encourage veterinary researchers to use the automated $\mathrm{CBC}$ considering the new parameters it offers, such as platelet-related data, not studied in depth until now.

In conclusion, the findings of the present study allow approximations to the definition of alterations in blood cells and counts, which can guide the treating veterinarian towards an early diagnosis in dogs, as well as define a base-line for future research approaches to estimate BRIs in canine populations.

\section{Declarations}

\section{Acknowledgements}

The authors thank Hemovital blood-bank in Medellín (Colombia) for support.

\section{Conflicts of interest}

The authors declare they have no conflicts of interest with regard to the work presented in this report.

\section{Author contributions}

Valentina Ochoa Ruiz: study design, data collection, data analysis, and manuscript construction. Víctor DVelasco Pérez: study design, data collection, data analysis, and manuscript construction. Margarita Patiño: sample processing and data collection. Jhonatan S Restrepo León: sample processing and data collection. Jannet Zapata Bailarín: data analysis and manuscript construction, critical reading, and edition. Nathalia M Correa-Valencia: data analysis and manuscript construction, critical reading, and edition. Patricia E Jaramillo Arbeláez: study design, data collection, data analysis, manuscript construction, critical reading and edition.

\section{References}

Barger M. The complete blood cell count: A owerful diagnostic tool. Vet Clin North Am Small Anim Pract 2003; 33(6):1207-1222. DOI: https://doi.org/10.1016/s0195-5616(03)00100-1

Bertazzolo W, Comazzi S, Sesso L, Scarpa $\mathrm{P}, \mathrm{Ru}$ G. Comparison of methods for determining platelet numbers and volume in Cavalier King Charles spaniels. J Small Anim Pract 2007; 48: 556-561. DOI: https://doi.org/10.1111/j.1748-5827.2007.00319.x

Barjatiya R, Geeta H, Jaskaran J, Savita M, Prakarti U. Comparative study of drum stick pattern in polymorph-nuclear neutrophil leucocytes in common mammals. Indian J Res 2016; 5: 39-41. Available in: https://pdfs.semanticscholar.org/1557/0cfb 99ae702fdcff4dff87ee8d588550fd0c.pdf? $\mathrm{ga}=2.211496720 .446519394 .1582917492$ $\underline{1971854196.1582734930}$ 
Bossa Miranda MA, Valencia Celis V del C, Carvajal Giraldo BA, Ríos Osorio LA. Valores de referencia del hemograma en perros sanos entre 1 y 6 años de edad, atendidos en el Hospital Veterinario - Universidad de Antioquia, 2002-2009. Rev Colomb Cienc Pecu 2012; 25: 409-416. Available in: https://www.redalyc.org/articulo. oa? id $=2950 / 295024923008$

Campora C, Freeman K., Lewis F, Gibson G, Sacchini F, Sanchez M. Determination of haematological reference intervals in healthy adult greyhounds, IDEXX Reference Laboratory, section of Veterinary Epidemiology, Vetsuisse Faculty, University of Zurich, Zurich, Switzerland. J Small Anim Pract (2011); 52: 301-309. DOI: https://doi.org/10.1111/j.1748$\underline{5827.2011 .01070 . x}$

Campuzano-Maya. Utilidad clínica del extendido de sangre periférica: los leucocitos. Medicina \& Laboratorio 2008; 14(9-10): 411455. Available in: https://www.medigraphic. com/pdfs/medlab/myl-2008/myl089-10b.pdf

Castellanos R, Castellano A. Estudio de valores referenciales para bioquímica sérica en población canina de la Parroquia San José, Distrito Valencia, Estado Carabobo. REDVET 2010; 11(5): 695-7504. Available in: https://www.redalyc.org/articulo. $\underline{\text { oa? } \mathrm{id}=63613160003}$

Chaterjee S. Reliability of sexual dimorphismin blood. Indian J Physiol Pharmacol 2014; 58(4): 400-402. Available in: https://pdfs. semanticscholar.org/48f1/63a3f3f2d75bde1fdc 88eac8963bd09c4d73.pdf

Clinical Laboratory Standards Institute (CLSI). Defining, establishing, and verifying reference intervals in the clinical laboratory. Approved guideline. 3rd ed. CLSI EP28-A3c. Wayne, Pennsylvania: Clinical and Laboratory Standards Institute; 2010. Available in: https://clsi.org/media/1421/ep28a3c sample.pdf
Day MJ, Mackin A, Littlewood JD. BSAVA Manual of canine and feline haematology and transfusion medicine. England: British Small Animal Veterinary Association. 2000. DOI: https://doi.org/10.1111/j.1748$\underline{5827.2012 .01283 . x}$

Geffré A, Concordet D, Braun J, Trumel C, Bourge N. Canine reference intervals for the Sysmex XT-2000iV hematology analyzer. ASVCP 2011; 40(3): 303-315. DOI: https://doi.org/10.1111/j.1939-165X.2011.00333.x

Gommeren K, Duchateau L, Paepe D, Vanholen L, Vandenberghe A. Investigation of physiologicleucopenia in Belgian Tervuren dogs. J Vet Intern Med 2006; 20: 1340-1343. DOI: https://doi.org/10.1892/08916640(2006)20[1340:ioplib]2.0.co;2

Grandía R, Fuentes R, Pérez J, Hernández J, Castillo M, Anicama W, Caballero J, Rojas L, Galindo I, Díaz L, Fimia-Duarte R. Hallazgos hematológicos en perros y gatos en Lima, Perú. Rev Inv Vet Perú 2019; 30(4): 1395-1413. DOI: http://dx.doi.org/10.15381/rivep.v30i4.17154

Gutiérrez V. Estudio comparativo entre el método de coloración de Wright y prueba de ELISA para el diagnóstico de Ehrlichiosis canina en la ciudad de San Pedro Sula, Honduras. Guatemala, 2008. Available in: http://www.repositorio. usac.edu.gt $/ 7432 / 1 /$ Tesis $\% 20 \mathrm{Med} \% 20$ Vet $\% 20$ Vilanova\%20Gutierrez\%20Mejia.pdf

Jácome LE, Duran M, Colín C, Ortega S, Cerón $\mathrm{G}$, Cendejas R. Las tinciones básicas en el laboratorio de microbiología. Rev Investigación en Discapacidad. 2014; 3(1): 10-18. Available in: https://www.medigraphic.com/pdfs/invdis/ ir-2014/ir141b.pdf

Jangsangthong A, Suwanachat P, Jaykum P, Buamas S, Kaewkongjan W and Buranasinsup S. Effect of sex, age and strain on hematological and blood clinical chemistry in healthy canine. J Appl Anim Sci 2012; 5(3): 25-38. Available in: https://vs.mahidol.ac.th/jaas/Files/Vol5No3/ Al1\%20Page $\% 20 \mathrm{JAAS} \% 203(5)^{\prime} 12 / 03 \% 20$ 


\section{JAAS $\% 203(5) \% 20 K$. Shutipen.pdf}

Jaramillo P, Acevedo P. Utilidad de los índices plaquetarios en el diagnóstico diferencial de enfermedades que cursan con alteraciones en las plaquetas. Hechos Microbiol 2010; 1(2): 7-45. Available in: https://revistas.udea.edu.co/index. $\mathrm{php} / \mathrm{hm} /$ article/view/9542

Lashari M, Hameed R, Farooq U, Idris M, Rehman Z. Sex determination through Barr bodies of neutrophils in human and dogs. Biologia (Pakistan) 2018; 64(1): 101-104. Available in: https://www.researchgate.net/ publication $/ 326812333$ Sex determination through Barr bodies of neutrophils in Humans and Dogs

Lavoué R, Geffre A, Braun J, Peeters D, Granat F, Bourges-Abella N, Trumel C. Breed-specific hematologic reference intervals in healthy adult Dogues de Bordeaux. ASVCP-WSVCP 2014; 43(3): 352-361. DOI: https://doi.org/10.1111/ vcp. 12151

Latimer K, Mahaffey E, Prasse K. Patología Clínica Veterinaria. Barcelona: Multimédica ediciones veterinarias. 2005 .

Lilliehook I, Tvedten $\mathrm{H}$. Investigation off hypereosinophilia and potential treatments. Vet Clin North Am Small Anim Pract 2003; 33: 1359-1378. DOI: https://doi.org/10.1016/ s0195-5616(03)00097-4

Merizalde M. Determinación de parámetros hematológicos, proteínas plasmáticas, valores de presión arterial y electrocardiografía en 300 caninos. Doctorate Thesis, Facultad de Ciencias Agropecuarias, Universidad de la Salle, Bogotá. 2011. Available in: https://pdfs.semanticscholar.org/6c4e/ d4a3dd9d97b6ac77fced882f5a9fb6cfaaa2. pdf? ga $=2.215697554 .446519394 .1582917492-$ 1971854196.1582734930

Mesa I. Estudio clínicopatológico del galgo español: Hemograma, análisis de gases $\mathrm{y}$ equilibrio ácido-base, electrolitos, antígeno eritrocitario canino DEA 1.1, bioquímica sérica, electroforesis de proteínas séricas y haptoglobina. Departamento de Medicina y Cirugía Animal, Universidad de Córdoba, 2015. Available in: https://helvia.uco.es/xmlui/ bitstream/handle/10396/12879/2015000001168 pdf? sequence $=1 \&$ isAllowed $=y$

Nielsen L, Kjelgaard-Hansen M, Lundorff Jensen A, Kristensen AT. Breed-specific variation of hematologic and biochemical analytes in healthy adult Bernese Mountain dogs. Vet Clin Pathol 2009; 39: 20-28. DOI: https://doi.org/10.1111/ j.1939-165X.2009.00186.X

Ozarda Y, Sikaris K, Streichert T, Macri J. IFCC Committee on Reference intervals and Decision Limits (C-RIDL). Distinguishing reference intervals and clinical decision limits - A review by the IFCC Committee on Reference Intervals and Decision Limits. Crit Rev Clin Lab Sci 2018; 55(6): 420-431. DOI: https://doi.org/10. $\underline{1080 / 10408363.2018 .1482256}$

Pedersen HD, Häggstrom J, Olsen LH, Christensen K, Selin A, Burmeister ML. Larsen $\mathrm{H}$. Idiopathic asymptomatic thrombocytopenia in Cavalier King Charles Spaniels is an autosomal recessive trait. J Vet Intern Med 2002; 16: 169-173. DOI: https://doi.org/10.1892/0891$\underline{6640(2002) 016<0169: \text { iatick }>2.3 . c 0 ; 2}$

Pedrozo R, Quintana G, Bazán A, Florentín, M. Valores hematológicos de referencia en caninos adultos aparentemente sanos, que concurren a una clínica privada de Asunción. Memorias del Instituto de Investigaciones en Ciencias de la Salud 2010; 8(2): 5-13. Available in: http://scielo.iics.una.py/scielo.php?script=sci abstract\&pid=S1812-95282010000200002\&ln $\mathrm{g}=$ en\&nrm=iso\&tlng=es

Singh MK, Lamb WA. Idiopathic thrombocytopenia in Cavalier King Charles Spaniels. Aust Vet J 2005; 83: 700-703. DOI: https://doi.org/10.1111/j.1751-0813.2005. tb13055.x

Smedile LE, Houston DM, Taylor SM, Searcy GP. Idiopathic, asymptomatic thrombocytopenia in Cavalier King Charles spaniels: 11 cases (1983- 
1993). JAmAnim HospAssoc 1997;33:411-415. DOI: https://doi.org/10.5326/15473317-33-5-411

Solbergn HE. Approved recommendations (1987) on the theory of reference values. Part 5. Statistical treatment of collected reference values. Determination of reference limits. J Clin Chem Clin Biochem. 1987; 25: 645-656. DOI: https://doi.org/10.1016/0009-8981(87)90151-3

Stockham SL, Scott MA. In: Fundamentals of Veterinary Clinical Pathology. 2nd ed. Eds S.L. Stockham, M.A. Scott. USA: Blackwell Publishing, Ames, IA, USA. 2008.

Thrall MA. Erythrocyte morphology. In: Veterinary Hematology and Clinical Chemistry. 2nd ed. Thrall MA, Weiser G, Allison RW. Campbell TW eds. Willey Blackwell. Oxford. 2012.

Villiers E, Blackwook L. Manual de diagnóstico de laboratorio en pequeños animales. Ediciones S. 2009.

Walton RN. Establishing reference intervals: Health as a relative concept. Semin Avian Exot Pet Med 2001; 10(2): 66-71. DOI: https://doi. org/10.1053/S1055-937X(01)80026-8

Willard MD, Tvedten $\mathrm{H}$, Tundwald $\mathrm{GH}$. Diagnóstico Clínico Patológico Práctico en los Pequeños Animales. Buenos Aires: Intermédica. 2004. 